\title{
DISCOVERING THE NATURE OF COMPETITIVE PERSONALITY
}

\author{
Diana B. Bogoyavlenskaya \\ Psychological Institute of the Russian Academy of Education \\ Moscow, Russia \\ Olga A. Klyueva \\ Tver State University \\ Tver, Russia
}

The concept of "competitiveness" has been most thoroughly developed in the framework of modern economics and management. Apart from economic factors, this concept also embraces social and psychological factors, but economic models do not reveal the psychological essence of the concept of "competitive personality."

Analytical review of the psychological and educational case studies of the competitive-personality problem has brought to light the ambiguity in this concept along with a multitude of models that distinguish individual aspects of a competitive personality. Most creators of the various models emphasize the quality of the conditions necessary for forming and developing a competitive personality.

In economics, competition is an essential, inherent feature of various types of activity where conflicts of interest occur. However, the established economic model of competitive personality reduces and replaces the psychological content of the concept.

Theoretically and experimentally the authors of this article substantiate their disclosure of the competitive-personality concept via its creative potential. Results of an in-depth study confirm that the ability to achieve success through one's own initiative, anticipating the demands of competition, appears to be the backbone for competitiveness of personality.

Keywords: Competitive personality, economic model of competitiveness, intellectual initiative.

In the context of rising living standards, having a competitive personality is the key to success in the global competitive struggle. Contemporary multifactor models of evaluating a country's global competi- 
tiveness include an evaluation of the labor force along with economic indicators.

The significance of human resources for an evaluation of competitiveness is pinpointed by the fact that some companies (Skandia, Dow Chemical, Canadian Imperial Bank of Commerce) are seeking to provide their shareholders and employees with detailed descriptions of "intellectual capital."

Thus, in the contemporary economic environment that has taken shape worldwide, the level of personal competitiveness determines the evolution of firms, entities, and the state.

For the first time on the national level, the importance of boosting the competitiveness of Russia was voiced in an address ("Russia at the Boundary of Epochs") by B. N. Yeltsin, the first president of the Russian Federation; the address was delivered at a joint session of the Russian Federation Federal Assembly on March 30, 1999. Boosting the competitiveness of Russia should become the keynote for our entry into the 21st century. In an economy everything is interdependent. If the competitiveness of the country is low, then capital inflow is lacking, as are progress, efficient production, and many other economic benefits. One of the causes for this state of affairs is that nobody has ever tackled competitiveness problems in Russia in a systematic and professional manner (Fatkhutdinov, 2004).

As mentioned by Andreev (2004), Bogoyavlenskaya (2002), Mitina (2003), Emelyanova (2008), Fatkhutdinov (2004), and others, becoming a competitive power requires that our specialists in science and in our leading manufacturing industries drastically boost their competitiveness. Therefore, regulations have now been developed and adopted for implementing the idea of increasing national competitiveness. The Council on National Competitiveness has been established; an independent, nonprofit organization for cooperation, the Council carries out activities aimed at boosting the global competitiveness of the country.

Creating competitive specialists has become a priority for the system of education, a project embodied in the policy documents in this sphere. For instance, training a qualified employee at an appropriate level and with an appropriate profile to be competitive in the labor market is presently a priority educational standard for the new generation.

The concept of competitiveness has been most thoroughly developed within modern economics and management and appears to be the key 
notion in the consideration of problems of organizational change. In accordance with modern views, competitiveness is the process used by an economic entity to manage competitive advantages - that is, the procedures that ensure dominance over rivals (Fatkhutdinov, 2004).

No wonder that the problem of competition and competitiveness and their role in social and human development gained the attention of thinkers quite a long time ago. We encounter one of the first references akin to the contemporary understanding of employee competitiveness in the myths and descriptions of ancient Greek thinkers - for instance in the myth of Hermes, the god of profit and enrichment: "to do a few things at once, get through here and there, assume a multitude of duties and perform them flawlessly" (Zaitsev, 2010, p. 55), and in Politics by Aristotle, specifically in the tale of Thales of Miletus (Aristotle, trans. 1984, p. 397):

He was reproached for his poverty, which was supposed to show that philosophy was of no use. According to the story, he knew by his skill in the stars while it was yet winter that there would be a great harvest of olives in the coming year; so, having a little money, he gave deposits for the use of all the olive-presses in Chios and Miletus, which he hired at a low price because no one bid against him. When the harvest-time came, and many were wanted all at once and all of a sudden, he let them out at any rate which he pleased, and made a quantity of money. Thus he showed the world that philosophers can easily be rich if they like, but that their ambition is of another sort.

The term competition had for a long time existed in ordinary language, but the Enlightenment marked the beginning of its use by thinkers in their scholarly works.

The alignment of the hereditary and estate privileges and the institution of democratic and market-economy principles in a number of countries were the historical prerequisites for introducing the scientific concept of competition. Adam Smith was a pioneer in using the concept of "free" competition. In An Inquiry into the Nature and Causes of the Wealth of Nations he points to free competition as a major tool of a perfect market economy and sees competition as rivalry that increases prices (in the case of a decrease in supply) or decreases prices (in the case of an oversupply). The main principle of competition is that an "invisible hand" "pulls" the threads of puppet-entrepreneurs and induces them to 
act in compliance with a "perfect" plan for developing the economy and to ruthlessly oust firms engaged in the manufacture of products that the market does not need (Kashpur, 2007).

Competition is undoubtedly an essential feature inherent in various types of activity where conflicts of interest occur (politics, economy, science, sports). This view of competition has been highlighted by both ancient Greek thinkers and contemporary researchers. For instance, Heraclitus viewed struggle as a source of everything existing in nature and in society. Seneca, a representative of late Roman stoicism, wrote, "In the strife for existence the animals armed with teeth and claws seem stronger than man, but nature has endowed man with two qualities that make this weak creature the strongest in the world: a mind and a society" (Seneca, trans. 2001, p. 507). Xenophon, Plato, Aristotle, Cato, Varro, and Columella noted the need for maintaining a slave-owning economy for profit; such an economy was a benefit of and a necessity for the adjustment of competitive relations (Gordeev, 2008).

In the opinion of E. Durkheim and K. Marx, competition is an impartial process of continuously improving quality, services, and so on. In economic and engineering development adjustable competition has been fruitful because the competitive struggle, especially at a time of crucial breakthroughs in engineering, induces the replacement of old instruments of labor with new ones prior to the natural death of the old ones.

P. Heine, I. I. Schmalhausen, Friedrich A. von Hayek, and J. Schumpeter held the opinion that competition is the process by which people obtain and transmit knowledge; it leads to good utilization of skills and expertise as most human benefits have been obtained through competition. Competition is the rivalry of the old and the innovative.

The social benefits of competition were widely covered by many schools of theoretical sociology in the 19th century: by utilitarianism (J. Bentham, J. Mill), social Darwinism (J. Sumner), H. Spencer's sociology. Mill stressed that "competition may not be the best conceivable stimulus, but it is at present a necessary one, and no one can foresee the time when it will not be indispensable to progress" (Mill, 1848/1980, p. 395).

In this context the statement by V. M. Bekhterev that no society can avoid competition, rivalry, and struggle is justified because this is the formula for future success and improvements (Bekhterev, 1994). 
The economic model of competitive personality unambiguously suggests that competition is a stimulus for development: "the universal striving for glory, honors and distinctions" that "induces developing and comparing abilities and powers" (Rousseau, trans. 2004, p. 766). Such a view, we believe, reduces the psychological content of the competitivepersonality concept.

In contemporary economic models a specialist's competitiveness embraces social and psychological factors apart from economic ones. But modern economic models do not reveal the psychological essence of the competitive-personality concept. Therefore it is quite logical that this concept has aroused interest in psychology and educational science since the mid-1990s.

Analytical review of psychological and educational case studies of the competitive-personality problem has brought to light the ambiguity in the concept and a multitude of models that distinguish individual aspects of the phenomenon of competitive personality.

Some researchers propose only the social and psychological traits of a competitive personality, but this concept does not concern the structure of personality and its components. Other surveys pinpoint only one personality component that appears, in the opinion of the authors, to be the backbone for competitiveness of personality - for instance, the system of values, the achievement motive, activity.

Most authors of various models emphasize that the determination and development of competitiveness of personality are based in the availability of competitors and the discrepancies between the external requirements of a profession and the environment, know-how, skills, and expertise of a person in that profession; they consider motivation for success and achievement a major component of a person's competitiveness. Surveys by McClelland (1961), Heckhausen (2003), de Charms and Moeller (1962) have revealed that economic upswings are preceded by the achievement motivation.

The prerequisite for forming a competitive personality is the availability of competition as rivalry, as contests between people, groups, and organizations in the pursuit of similar goals and of improved results in a specific public sphere.

The summary article by Zhuravlev and Ushakov (2009) convincingly indicates that in many cases debates over problems of economic growth show a drastic shift toward psychologization (enhancing the 
role of psychological factors) in both the perception and the interpretation of social processes. The authors believe that the achievement motivation ensures competitiveness of personality in areas of activity that require high exertion and constant surmounting of obstacles, particularly in entrepreneurship. Specifically, they refer to McClelland (1961). The ability to think independently, which is the result of education, may also contribute to the development of an economy based on private enterprise. The article cites the opinion of R. Lynn and T. Vanhanen, who view national intelligence as a factor relevant to the economic welfare of any country. Indeed, general intelligence has been the most powerful predictor in psychology for individual professional achievements. On average, it correlates at the level $r=0.58$ with success in strenuous intellectual professions and at the level $r=0.23$ with success in simple manual labor. It is asserted that general intelligence appears to be a more powerful predictor of economic growth than market freedom, democracy, investments, various parameters of the education system, and so forth. However, the authors emphasize that intelligence plays a more significant role in cognitively strenuous professions than in cognitively simple ones and in professions of the "human-object" and "humansymbol" types.

For the professions, the success of which is related to the creation of a fundamentally new original product, creativity takes the foreground. The article gives convincing evidence that the role of creativity in the making of a country's competitiveness is enhanced by the fact that creative achievements in a society are distributed quite unevenly. An insignificant minority of the people produces the major part of the creative product.

At the same time the authors stress that psychological traits influence the success of the country indirectly, via the phenomenon of human capital, which incorporates psychological traits and some others - for instance, professional competence.

However, professional competence needs to be constantly updated, and a lack of the psychological traits required for it to be adequately developed and applied, rather than privacy of information, is the worst hindrance to the improvement of such competence. In this respect, the most advanced approach is the one suggested by L.M. Mitina, who views competitiveness as a result of transforming one's own life activity into the subject matter for practical reform. The object of development is in- 
tegral personality traits (focus, competence, flexibility). In the studies in this area, activity and motivation for success in a professional occupation appear to be the major parameters in the structure and content of the competitive personality (Mitina, 2003; Podosinnikova, 2007).

As a positive aspect of the article by Zhuravlev and Ushakov (2009) one should note that, contrary to the view prevalent in economic models of competitive personality, the authors consider such traits as competitive motivation and attitude toward competition as additional personal traits.

At the same time, we recognize such traits of personality as "focus on cause" to be decisive in competitive personality. Suffice it to recall that in the disclosure of the structure of genius F. Galton identified "devotion to cause" as a specific trait of the general genius.

Devotion to cause accounts for the human ability to develop an activity that has an inherent value, sometimes the meaning of life, on one's own initiative rather than through external circumstances. In a whole cycle of studies we have proved that this ability to develop an activity on one's own initiative may be deemed as the unit for analyzing the creativity and genius of a personality.

The developed psychodiagnostic method of Creative Field makes it possible to identify the ability to develop activities on one's own initiative (Bogoyavlenskaya, 2002).

By analogy with art, which appears to clearly differentiate between competence and art, in science an activity that is realized highly successfully but is always externally stimulated may be deemed to involve competence rather than creativity. In that case the tasks being performed by a person are singular because as soon as the desired effect has been achieved, the process of thinking terminates. We call that level of activity the stimulus-productive level. Development of an activity on the initiative of the subject causes the discovery of new regularities as generalization on the level of the particular. This type of creativity is called heuristic in our typology. In the philosophical literature it has been viewed as a manifestation of genius. On the final level the discovered new regularity is theoretically grounded. On the scale of discovery, this is the level of the universal. Such analysis enables us to reveal the essence of the phenomenon and provides the opportunity to predict qualitative leaps in its development. Hence, the method reveals prognostic abilities. Within the problem of competitive personality this trait guarantees maximum ad- 
vantage because it enables one to excel and to be prepared for situations that may emerge in the future.

One cannot fail to note that this trait to a definite extent makes it possible to comprehend why the scientists and general thinkers whom we refer to as geniuses may surpass the level of social knowledge, sometimes by centuries. It is noteworthy that some authors (Heine, Schmalhausen, von Hayek, Fatkhutdinov) regard the ability to develop and predict as the basis for competition.

We believe that the ability to develop an activity on one's own initiative is the backbone component in competitiveness of personality. This ability ensures the progressive evolution of the activity, the innovative product of which permanently outdistances the defined original conditions of competition and causes the "composition of the subject itself" because "the subject in his/her deeds, acts of creative self-activity, is not only discovered and manifested, but is also created and defined" (Rubinstein, 1986, p. 107).

Results of our study provide evidence for these conclusions. We conducted a free interview with 1,000 representatives of various professions. The study covered respondents aged 16 to $70(M=36), 42 \%$ of the sample being men, $58 \%$ being women. Out of 1,000 respondents, $16 \%$ had a general secondary education; $36 \%$, a vocational secondary education (undergraduate education); 48\%, a higher education. By profession, $10 \%$ of the total sample was made up of directors at various levels, $39 \%$ were managers, $28 \%$ were specialists at different levels, $8 \%$ were students, $9 \%$ were school students, $4 \%$ were pensioners, and $2 \%$ were unemployed. At our request the respondents described a specific example of a competitive personality and its advantages in a competitive environment.

A content-analytical study of the free interview was aimed at revealing sociopsychological traits in the image of the competitive personality held by representatives of various professions. Under sociopsychological traits in the image we understand there to be a set of personality traits most significant for winning in competition.

In view of the sampling characteristics, it should be noted that we have not discovered statistically significant correlative relationships between the variables. A weak (negative) correlative relationship exists only between such variables as notion of competitiveness of personality, sex, age, motive, and education. This finding can be explained by the 
unequal distribution of the subjects by age groups, given the phases of professional development as the subject of labor.

In the opinion of $82 \%$ of respondents, competitiveness of personality is based on the striving for victory, the willingness to be first and to be better than your rival, the achievement of a goal, and career progress or the avoidance of punishment.

Ninety-two percent of respondents believed that a competitive environment stimulates the mastery of professional competence and the efficiency of activity.

Oksana K. (age 27), a manager at a large Moscow bank, answered the questions of the free interview in this way: "Competitiveness of personality means, primarily, professionalism that has been recognized by the community of fellow professionals. A competitive personality is the best among such professionals. The striving to be competitive has been conditioned, first and foremost, by pecuniary interest (profit, salary, or wage level, etc.). Only once the given level has been achieved, do other interests arise."

Along with a wide selection of sociopsychological traits respondents point out a series of external criteria that characterize the success of a competitive personality in a professional activity: salary or wage level, career, position occupied and its place in the organizational chart. Professional success is a collection of positive results accumulated during an entire career, both in one's psychology and in objective professional achievements, according to contemporary foreign studies. Hughes (1958), van Maanen (1977), Hammer (2008), and others have proposed a division into objective and subjective career results. Objective success consists of positive career results that surrounding persons may assess. As a rule, it is measured by such characteristics as salary or wage level, number of job promotions, and level of the position occupied in an organization. Subjective success consists of a collection of a person's judgments about his/her professional achievements and results. It is measured by the parameters of job and career satisfaction. Hence, according to the implied model of the competitive personality, characteristics of professional success are components of personality structure (Hammer, 2008).

Nonetheless, $18 \%$ of respondents maintained that the basis for competitiveness of personality lies in professional interests "even for their own sake." As an example we cite a summary reply of a respondent: 
S.B. is a joiner. His products are works of art, masterpieces. S.B. himself provides the following explanations: "I love wood; it seems to me I even feel it. Besides, I've read over a bulk of literature about the ways of working with wood and things that could be made of it, as well as about trees as such. The work with wood is my vocation. I've realized that and want to be engaged in nothing else." Apart from his professional skills S.B. likes his job, he feels the material. He shows more than just a careful attitude toward what he is doing. To all appearances, his work is his favorite occupation. This is the quality of a person who is hard to compete with. In a contest of joiners held in Kostroma in 2009 S. B. won prizes. The task was to make a chair. S.B. was the only one who made it of a whole lump of wood. Other craftsmen made knockdown chairs - that is, by parts.

Yaroslav K., age 41, is a manager at a Sberbank branch. A nominee for Manager of the Year-2008 in the Tver region, Yaroslav answered the questions in the free interview in this way:

In general, one can discuss long-term and short-term competitiveness. The short-term competitiveness of personality implies achievement of a goal by any means whatsoever, even by those that are not quite fair. The result has been obtained, but its influence and significance have been of a short-term nature. As far as long-term competitiveness is concerned, this is long-term work that involves professionalism, fairness, and definite business qualities. Nowadays, the majority of organizations have a low competitiveness level. They lack precise comprehension of what this is - the opportunity to compete on an equal footing with Western entities, the discrepancy in the level of education and the requirements of the labor market and of employers. The desire for high performance in a professional activity is the major motive for competitiveness.

Dmitry Sh. (age 32), head of the IT department at a large Moscow firm, answered:

When hiring, during the interview we compare the contenders (applicants) for a job and choose the best. A desire to succeed motivates one to be competitive, although the understanding of success has a subjective nature. For some, success is recognition by colleagues or obtaining high profits, while for others it is a professional task resolved in a new manner (the novelty of which can be assessed only by a narrow range of specialists). A human being is an integral creature in which everything is interrelated. The major 
qualities of competitiveness include professionalism, competence, precise goals, flexibility, responsibility, ability to search for solutions in a new situation, application of new technical aids. The driver for the development of competitiveness is to aspire for more, to learn, to be engaged in the process of self-development. In professional activity it is manifested as setting a goal and achieving it, which predetermines the next step - a new goal.

According to the descriptions from our respondents, they do not suspend analyzing their activity even when it is successful. By permanently improving, implementing all the new ideas that originate in the process of work, they get, as a result, a new product that goes substantially beyond the original conception or original requirements. This is a case of the progressive evolution of the activity on the person's own initiative.

We can conclude from the above descriptions that such characteristics as salary or wage level, number of job promotions, and level of the position occupied in the hierarchy of an organization are the criteria for positive success in a career - that is, objective success in a professional occupation. Most of the researchers maintain that objective success and achievements in a professional occupation are the fundamental components of competitiveness of personality.

With the aid of the monographic method of personality examination (autobiographical questionnaire, interview, analysis of official documents), using the criteria of objective success and achievements in a professional occupation, from the total sample we selected a group of the most successful professionals; these respondents subsequently participated in a psychodiagnostic survey using the Creative Field method.

The results obtained indicated that the Creative Field method differentiates subjects who are successful and have achievements but who are not differentiated by outwardly objective success indicators. Singling out the essential characteristics of the sheer competitiveness of personality inherent in our participants who attained the heuristic level simultaneously allows setting apart the factors at the expense of which subjects of the stimulus-productive type who are unable to develop activities on their own initiative attain success in the modern environment (Bogoyavlenskaya, 2002).

The data derived from the application of the Creative Field method corroborate results of the monographic personality examination. Anal- 
ysis of the professional success of subjects at the stimulus-productive level makes it possible to conclude that the common criteria of objective success and achievements in a professional occupation may be formal in nature. Thus, for instance, I.V. is a successful entrepreneur with a high income. She owns a large retail chain and has occupied a leading position in the market for over 10 years. In the experiment that utilized the Creative Field method I.V. did genuine and strenuous work. She quickly mastered the primary mode of action for solving a series of tasks offered to her; such mastery confirms a sufficiently high level of intelligence. In the Raven Standard Progressive Matrices, she was level II, which coincides with the data on learning ability in the Creative Field. However, during the entire experiment I.V. utilized only the initially discovered and reliable method of performing the tasks. I.V. focused mainly on the time spent, just like all those who are looking at the assessment rather than the process. If time is the major indicator of success, it rules out risk and any investigative activity. For these reasons I.V. is characterized as being at the stimulus-productive level of activity. I.V. answered the questions in the free interview in this way:

The basis for competitiveness of personality is the goal that you're striving for. Achievement of a target goal ensures the entire process of self-development, development of the occupation you are engaged in. I do not quite agree that pecuniary interest is the only basis for competitiveness. For instance, my business has been stable presently. The income I receive is quite high, permanent, and changes only slightly. And now I want to turn to indepth study of the products, the experience of others, and to consider the development and improvement of my business. This is where my creative abilities will show up.

The respondent noted that only in conditions of stable business and high permanent income - that is, under favorable external circumstances - is she willing to perform an in-depth analysis of her professional activity. In other words, the development of an activity by I.V. is possible only if stability in business is guaranteed.

Our results could be viewed, in addition to being in-depth diagnostics, also as a prognosis. They could serve as a basis for prediction of the future success of both our participants and the businesses they are running. As of now, I.V.s business is not developing; it has been stable but the level of income is decreasing. The range of goods has shrunk, and no 
variety is present, contrary to the situation of rivals. The leading position in the market has been lost.

Our study, conducted on a considerable sample, allows us to maintain that the ability to develop an activity on one's own initiative - that is, the creative abilities of the personality - constitute the backbone of the competitive personality and thus ensure its increased resources.

\section{References}

Andreev V.I. (2004). Konkurentologija [Competology]. Kazan: Innovative Technologies Center.

Aristotle (trans. 1984). Politika [Politics], vol. 4. Moscow: Mysl.

Bekhterev, V.M. (1994). Izbrannye trudy po sotsialnoj psihologii [Selected works in social psychology]. Moscow: Nauka.

Bogoyavlenskaya, D.B. (2002). Psihologiya tvorcheskih sposobnostej [The psychology of creative abilities]. Moscow: Academia.

de Charms, R., \& Moeller, G.H. (1962). Values expressed in American children's readers: 1880-1950. Journal of Abnormal and Social Psychology, 64, 136-142.

Emelyanova, L.A. (2008). Psihologiia konkurentsii i konkurentosposobnosti [Psychology of Competition and Competitiveness]. Moscow: MGOU publishing.

Fatkhutdinov, R.A. (2004). Upravlenie konkurentosposobnostyu organizatsii [Managing an organization's competitiveness]. Moscow: Eksmo.

Gordeev, V.A. (2008). Sovremennaia konkurentsiia: Edinstvo "ugasaniia" i obostreniia [Contemporary competition: The cohesion of "decay" and aggravation]. Vestnik Ivanovskogo Gosudarstvennogo Universiteta [Bulletin of Ivanovsk State University], 4, 6-15.

Hammer, Y.S. (2008). Professionalny uspeh i ego determinant [Professional success and its determinants]. Voprosy Psihologii [Psychology Issues], 4, 147-154.

Heckhausen, H. (2003). Motivatsia i Deatelnost [Motivation and activity]. St. Petersburg: Piter.

Hughes, E.C. (1958). Men and their work. Glencoe, IL: Free Press.

Kashpur, V. V. (2007). Poniatie "konkurentsija" v issledovanijah sistemy obrazovaniia: Metodologicheskie osnovanija primenenija [The concept of "competition" in studies of the educational system: Methodological grounds for application]. Vestnik Tomskogo Gosudarstvennogo Universiteta [Bulletin of Tomsk State University], 298, 42-44.

McClelland, D. (1961). The achieving society. Princeton, NJ: Van Nostrand.

Mill, J.S. (1980). Osnovy politicheskoj ekonomii i nekotorye aspekty ih primenenija $k$ sotsialnoj filosofii [Principles of political economy with some of their applications to social philosophy]. Moscow: Progress. (Original work published 1848) 
Mitina, L.M. (2003). Psihologiia razvitiia konkurentosposobnoj lichnosti [The psychology of developing a competitive personality]. Moscow: Moscow Psychology and Sociology Institute; Voronezh: NPO Modek.

Podosinnikova, E.A. (2007). Psihologicheskie usloviia razvitija konkurentosposobnosti molodyh spetsialistov $v$ protsesse professionalnoj dejatel'nosti [Psychological conditions for the development of competitiveness in young specialists in the process of professional activity] (Unpublished doctoral dissertation in psychological science, no. 19.00.13), Astrakhan: Astrakhan State University .

Rousseau, J.-J. (trans. 2004). Ispoved. Progulki odinokogo mechtatelya. Rassuzhdenie o naukah $i$ iskusstvah. Rassuzhdenie o proishozhdenii i osnovaniyah neravenstva mezhdu lyudmi [Confessions. Reveries of a solitary walker. A discourse on the sciences and arts. Discourse on the origin of inequality]. Moscow: AST.

Rubinstein, S.L. (1986). Printsip tvorcheskoj samodeyatelnosti. K filosofskim osnovam sovremennoj pedagogiki [The principle of creative self-activity. Toward the philosophical fundamentals of contemporary pedagogy]. Voprosy Psihologii [Psychology Issues], 4, 101-109.

Seneca (trans. 2001). "O blagodeyanijah" [On Benefits]. In Antologija mirovoj filosofii. Antichnost. [Anthology of world philosophy. The ancient world]. Moscow: AST; Minsk: Harvest.

van Maanen, J. (1977). Experiencing organization: Notes on the meaning of careers and socialization. Organizational careers: Some new perspectives (pp. 15-45). New York: Wiley.

Zaitsev, Y.V. (2010). Mify drevnej gretsii [Myths of ancient Greece]. Moscow: Belyj Gorod.

Zhuravlev, A.L., \& Ushakov, D.V. (2009). Obrazovanie i konkurentosposobnost natsii: Psihologicheskie aspekty [Education and the competitiveness of the nation: Psychological aspects]. Psihologicheskij Zhurnal [Psychological Journal], 30(1), 5-13. 